\title{
Determinants of Kenyan Tea Exports: The Gravity Model Approach
}

\author{
Martin Ndemo Sato \\ Agriculture Information Institute (AII), Chinese Academy of Agricultural Sciences, \\ Haidian, Beijing 100081, China
}

\begin{abstract}
Tea exports are one of the primary drivers of economic growth in Kenya. Given its importance in the economy, it is necessary to analyze factors that are determining tea export flows between Kenya and its trading partners. In this paper, the key factors determining Kenya's tea exports to its major 15 trading partners for the period 1990 to 2017 were analyzed using a gravity model method. For this purpose, the secondary data were collected from official websites of the United Nations as well as other reliable sources. The main findings suggest that an increase in the economic size of importing country and depreciation of Kenyan shilling increases tea exports. On the other hand, an increase in population and per capita GDP of the importing country decreases the demand for tea, leading to a reduction of tea exports. Distance is used as a proxy of transportation cost and it is found to have a negative impact on tea exports. Having a common border and trading with countries that are non-landlocked allows the delivery of Kenyan tea at minimum transportation cost, which increases the export flow of tea from Kenya. Moreover, the results reveal that countries that Kenya shares a common colony with and COMESA members have a strong tendency to receive tea exports from Kenya. These results are essential for the formulation of trade policy to ensure that Kenya's tea export potential is exploited to boost economic growth and generate employment.
\end{abstract}

Keywords: Gravity model, Kenyan tea exports, panel data, fixed effects, random effects, pooled effects

DOI: $10.7176 / \mathrm{JESD} / 10-14-15$

Publication date:July $31^{\text {st }} 2020$

\section{Introduction}

Exports are defined as economic and commercial activities that are regarded as being of great importance for the economic growth and sustainability of nations (Houghton \& Sheehan, 2000). This is mainly a crucial means of acquiring currencies, which are the means of economic and financial intervention in a country's external markets. Exports are essential to the process of growth and a necessary part of the economic growth process is expanding exports This is evident in Kenya's agricultural sector, which has been significant in foreign exchange generation and employment creation over the past decade

Agriculture, including livestock, forestry, and fishing, accounts for approximately $27 \%$ of Kenya's GDP and $60 \%$ of export earnings from commodity trading(Awokuse \& Xie, 2015). Agricultural growth also has strong links with the broader economy: it is estimated that $1 \%$ of agricultural growth will drive overall GDP growth of $1.6 \%$. In 2018 the ILO estimated that $57 \%$ of Kenya's total employable population of 28 million earn some income from agriculture, including farmers and other off-farm employment related to agriculture (e.g., agri-businesses), Supporting the sector will ensure the livelihood of the majority of the Kenyan people. Existing studies indicate that growth in the agricultural sector in Africa is more successful than similar development in other sectors in reducing poverty (Christiaensen, Demery, \& Kuhl, 2011)

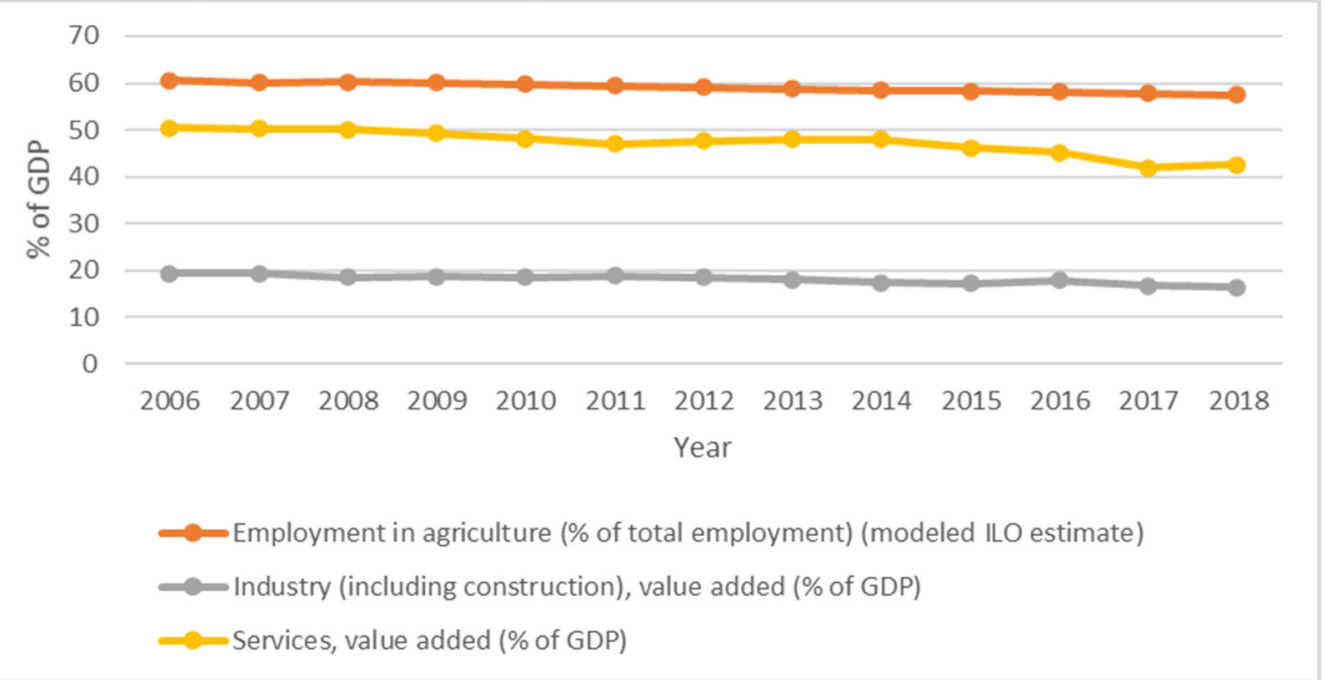

Figure 1: Structure of the Kenyan economy (Source: World Bank Development Indicators) 
Kenya's share of international trade is insignificant, with primary products dominating the export sector. The country's major agricultural exports are tea, coffee, and horticultural products (Jensen \& Sandrey, 2015). In 2017, Kenya exported $\$ 6.17 \mathrm{~B}$, making it the 101st biggest exporter in the world. Over the last five years, Kenya's exports have increased by $4.4 \%$ annually, from $\$ 4.89 \mathrm{~B}$ in 2012 to $\$ 6.17 \mathrm{~B}$ in 2017 (FAO FAOSTAT, 2018). The most recent exports are tea, accounting for 22.3 percent of Kenya's total exports, followed by horticultural products, accounting for 11.2 percent of Kenya's total exports, then $4.3 \%$ coffee and the remaining $52 \%$, including other agricultural and non-agricultural commodities.

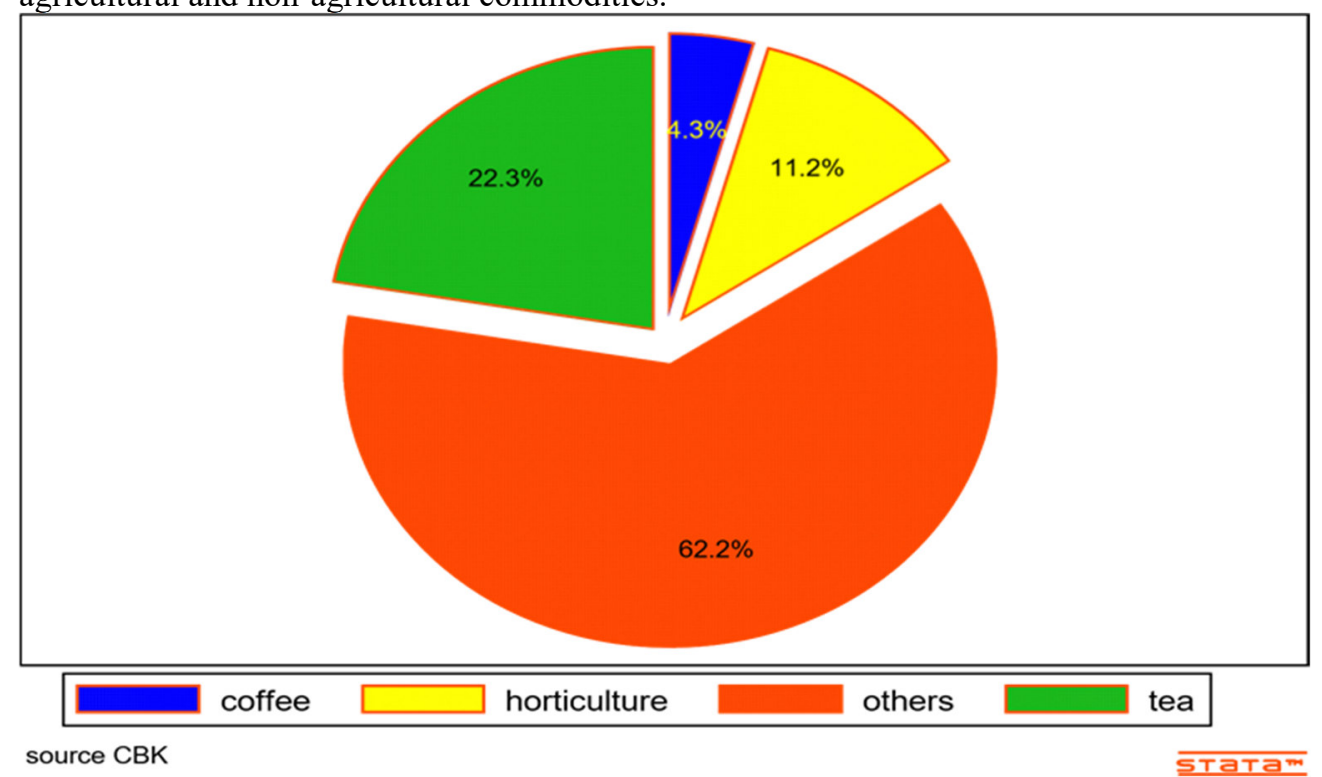

Figure 2: Structure of Kenyan Exports

Given the importance of tea to the economy of Kenya, it is essential to recognize factors affecting its international trade and marketing and to understand the factors that can help maximize market potential. Using this type of information will help the industry expand, add to foreign exchange earnings, reduce the overall trade deficit in the country and improve economic growth.

The gravity model is the foremost prevalent approach utilized to estimate international trade flows. ( Abler 2007). It is commonly used to calculate at an aggregate level the potential and factors affecting bilateral trade flow (Brülhart \& Kelly, 1999; Hatab, Romstad, \& Huo, 2010; Lof, Mekasha, \& Tarp, 2015; Ricchiuti, 2004). However, few studies have tried to apply it at a specific commodity level, e.g. (Ahmad \& Garcia, 2012; Dascal, Mattas, \& Tzouvelekas, 2002; Orindi, 2010) and its application to Kenya has been very limited. This study is an addition to that literature by applying a gravity model to measure the commodity-specific export potential of Kenyan tea exports using panel data on exports to 15 tea markets for 1990-2017 and to investigate the economic, geographical and cultural factors that affect tea exports.

\section{Overview of the tea sector in Kenya}

In 1903, the British colonists brought tea from India to Kenya. The colonial government initially limited the cultivation of the country's major cash crops, tea, and coffee to multinationals of large-scale settlers (Cheruiyot, 2013; Commission, 2008). After independence in 1963, tea cultivation was unbundled with local farmers who began buying small shares of tea land. The cultivated area and tea production have since increased significantly. The overall area under tea cultivation and production increased from 21,500 hectares of tea and 18,000 tons produced in 1963 respectively to 120,000 hectares and almost 300,000 tons by the end of the century (Food Faostat, 2018). Today, Kenya is the world's third-largest tea producer after China and India, with an output that rounds 350,000 tons per year. 


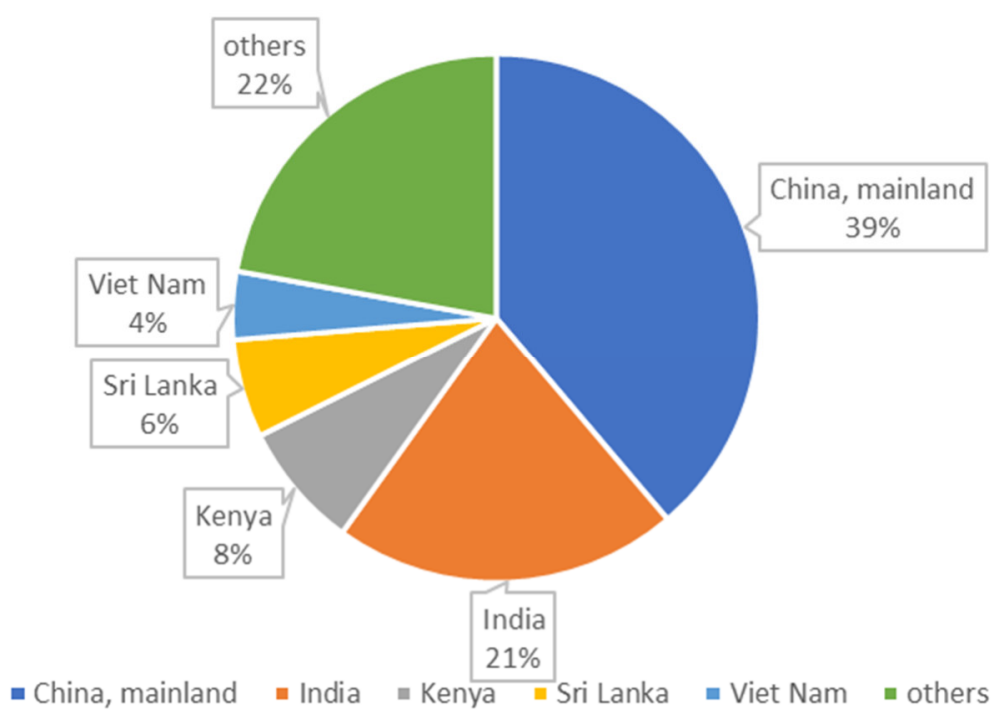

Figure 3: World Tea Production 2013-2017 (Source: International trade statistics)

Mulinge, Witwer, and Monroy (2013) pointed out that Kenya consumes only about 5\% of its production, unlike the other world's leading tea-producing countries. With the rest being exported, Kenyan tea production accounts for around $21 \%$ of the world's tea exports; this makes the tea industry in Kenya one of the significant contributors to national income and the biggest employer of the private sector.

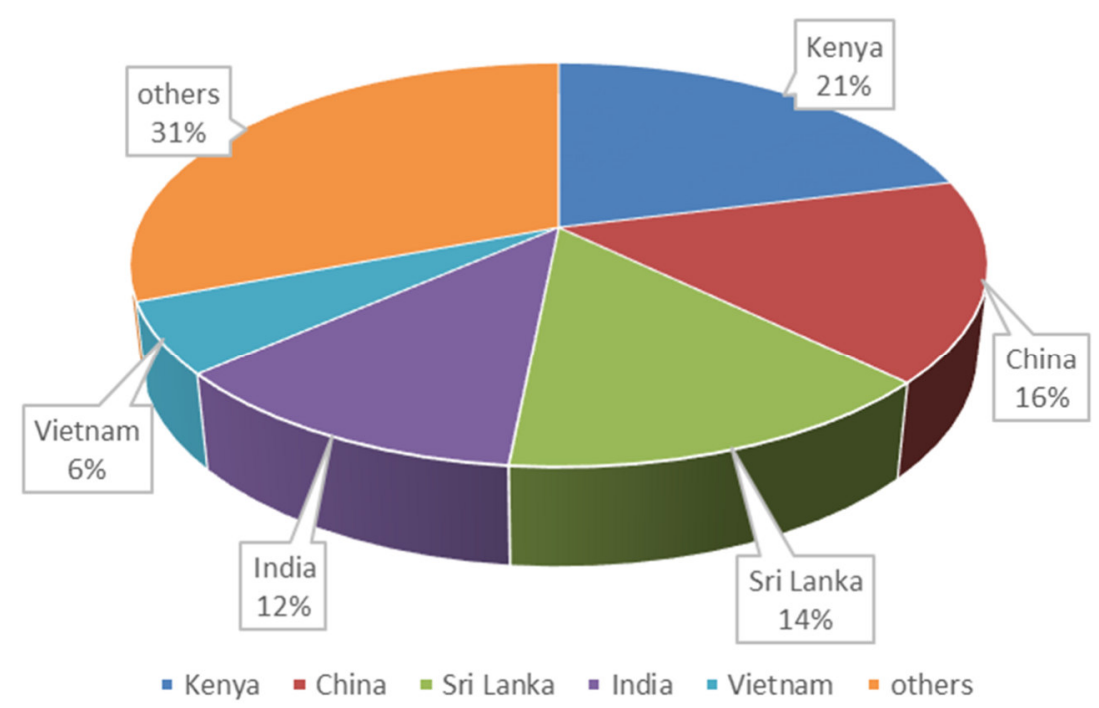

Figure 4: World Tea Exports 2013-2017 (Source: Resource Trade)

The leading destination of Kenyan tea exports is Pakistan, Egypt and the UK, accounting for more than 54 percent of national tea exports (Figure 5). Pakistan alone accounts for $27 \%$ of tea exports overall. 


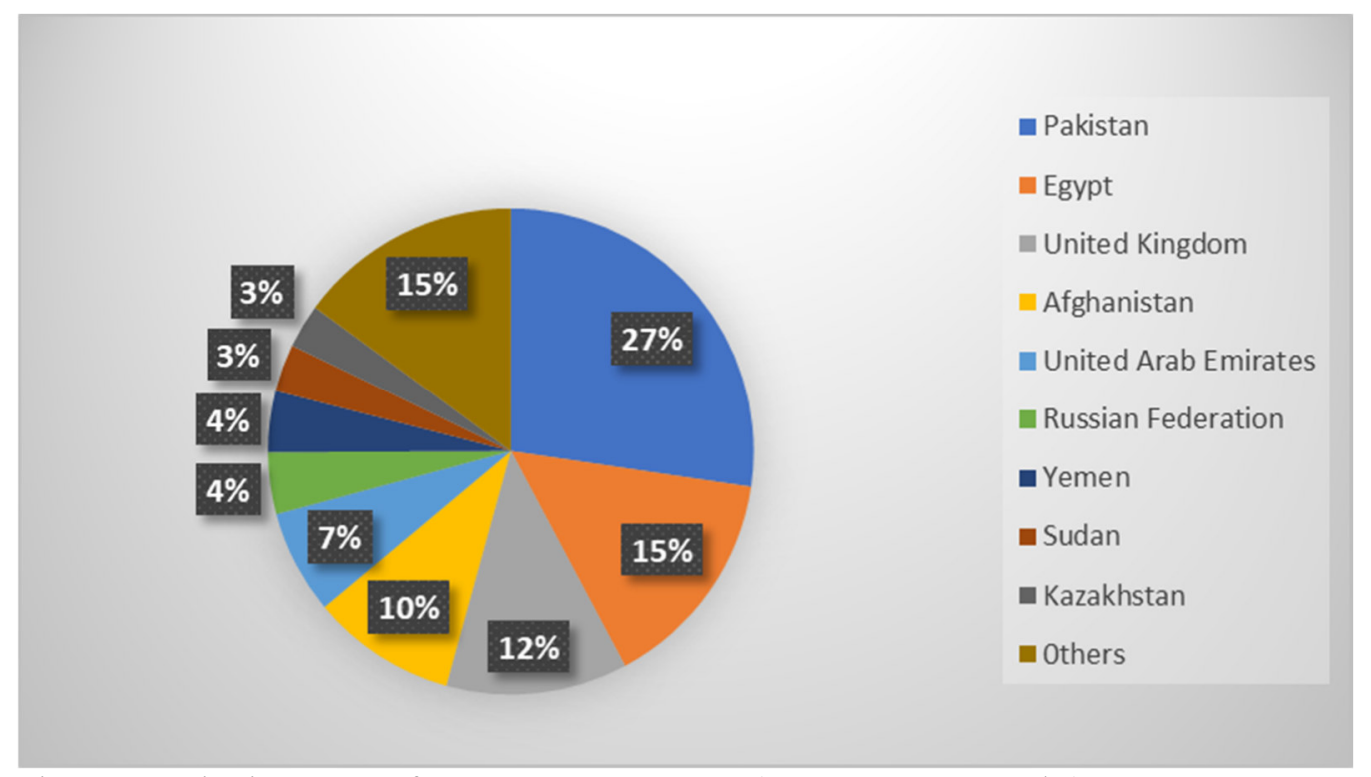

Figure 5: Major importers of Kenyan tea 2010-2018 (Source: UNComtrade )

Over the past few decades, tea production in Kenya has been steadily increasing, mainly due to the steady growth of the plantation area, mostly by smallholders. As shown in Figure 3, the specific annual production upand-downs are due to changes in production yields. During the decade of 15 years 2001-2017, Kenya's tea production showed a general upward trend, supported by the steady rise in the harvested area. Nonetheless, production declines are due to a reduction in the productivity of the land.

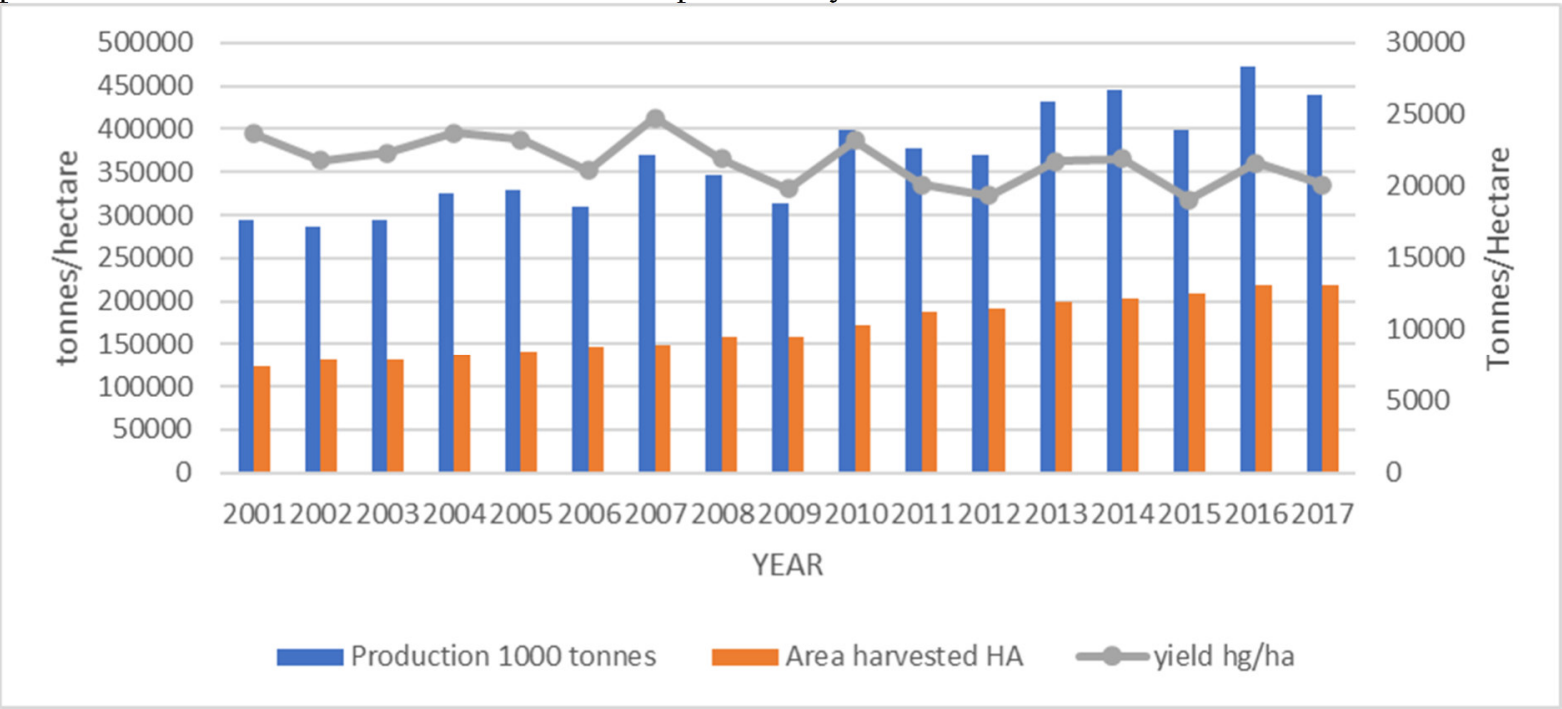

Figure 6: Tea Production, Area Harvested and Yield in Kenya, 2001-2017 (Source: Faostat )

\section{Methodology and data}

\subsection{Foundation of the model.}

To examine the determinants of tea exports from Kenya, this paper utilizes a gravity model that has been commonly implemented by various literature to investigate the determinants of bilateral trade flow. Tinbergen (1962)and Linnemann (1966) first implemented this model and Anderson (1979) later developed it. The model is based on the universal law of physical gravity of Newton, which states that the appeal of gravity of two objects is proportional to their masses and reverses their distance squared as shown in equation 1:

$X_{i j}=Y_{i}^{\beta_{i}} y_{j}^{\beta_{j}} D_{i j}^{\beta_{3}} \ldots \ldots \ldots \ldots \ldots 1$

Where xij denotes the exports from country $i$ to country $j$; yi and yj is the GDP of country I and $j$ respectively and Dij is the geographical distance between country I and country $\mathrm{j}$.

A variation of the gravity model presented by (Hatab et al., 2010) is the model used in this paper as discussed 
in the literature review equation

$x_{i j}=\beta_{0}\left(Y_{i}\right)^{\beta_{1}}\left(Y_{j}\right)^{\beta_{2}}\left(D_{i j}\right)^{\beta_{3}}\left(A_{i j}\right)^{\beta_{4}}\left(U_{i j}\right)$ .2

Where $\mathrm{Yi}$ is origin country I's gross domestic product; $\mathrm{Yj}$ is destination country $\mathrm{j}$ 's gross domestic product; Dij is the physical distance between the origin and destination countries; Aij stands for any other factors that affect trade flows between the origin and destination country, and uij is an error term representing any factors that are not considered in this equation but may affect bilateral trade flows.

\subsection{Specification of the model}

(Cortes, 2007) Noted that additional variables can be added to improve the fundamental methodology of the selected gravity equation. In contrast, this inclusion of variables provides an opportunity to adopt the gravity equation to specific circumstances of the bilateral trade understudy. To understand better Kenya's flow, we have added several additional variables as explanatory variables. This paper also introduces dummy variables such as common border, island and trading blocs like COMESA and EU. Based on the literature, discussed previously, the estimable gravity model of exports could be specified as follows:

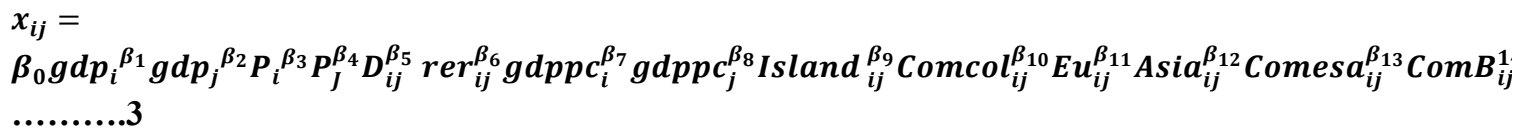

Where $\mathrm{x}$ is the exports, GDP is the gross domestic product, $\mathrm{p}$ is the population, $\mathrm{D}$ is the geographical distance in $\mathrm{Km}$ rer is the exchange rates gdppc is the gross domestic product per capita income comcol is the common colony, EU is European union, Asia is an Asian country, Comesa is Common Market for East and South Africa, ComB is the common border and WTO is world trade organization.

By taking the natural log of equation 3 and separating the individual country effects from the error term, the linear form of the final model to be estimated becomes;

$$
\begin{aligned}
& l X_{i j t}=\beta_{0}+\beta_{1} l\left(g d p_{i t}\right)+\beta_{2} l\left(g d p_{j t}\right)+\beta_{3} l\left(P_{i t}\right)+\beta_{4} l\left(P_{j t}\right)+\beta_{5} l\left(D_{i j}\right)+\beta_{6} l\left(\operatorname{rer}_{i j t}\right)+ \\
& \beta_{7} l\left(\text { gdppc }_{i t}\right)+\beta_{8} l\left(\text { gdppc }_{j t}\right)+\beta_{9} l\left(\text { island }_{j}\right)+\beta_{10} l\left(\operatorname{ComCol}_{i j}\right)+\beta_{11} l\left(\text { eu }_{j}\right)+\beta_{12} l\left(\text { Asia }_{j}\right)+ \\
& \beta_{13} l\left(\text { Comesa }_{j}\right)+\beta_{14} l\left(\text { commonB }_{i J}\right)+\beta_{15} l\left(\text { WTO }_{j}\right)+\left(U_{i j t}\right) \ldots \ldots \ldots . .4
\end{aligned}
$$

Where

I is the exporting country and for the case of this study $i$ is Kenya while $\mathrm{j}$ is the trading partner and $\mathrm{t}$ is time in years

$X_{i j t}$ is the value of Kenya's tea (in US dollars) exports to country $\mathrm{j}$;

$g d p_{i t}$ and $g d p_{j t}$ is the gross domestic product of Kenya and country $\mathrm{j}$ at time $\mathrm{t}$ respectively;

$P_{i t}$ and $P_{j t}$ is the population of Kenya and country $\mathrm{j}$ at time $\mathrm{t}$ respectively;

$D_{i j}$ is the geographical distance in kilometers between the capital city of Kenya to the capital city of country $\mathrm{j}$;

$\operatorname{rer}_{i j t}$ is the real exchange rates between Kenya and country $\mathrm{j}$ at particular time $\mathrm{t}$;

$g d p p c_{i t}$ and $g d p p c_{j t}$ is the gross domestic product per capita for Kenya and trading partner respectively;

island $_{j}$ is a dummy variable whether the trading partner is not landlocked coded as one or landlocked coded as zero.

$\mathrm{ComCol}_{i j}$ shows the colonial linkage; if Britain colonized the trading partner, it takes value one and if not, it takes value zero.

$e u_{j}$ European country a dummy coded as one and zero otherwise;

comesa $_{j}$ is a dummy variable if a trading partner is a Comesa member is coded one and zero otherwise;

Asia $_{j}$ Asian country a dummy coded as one and zero otherwise;

common $B_{i j}$ is a dummy variable taking value one the trading partner $\mathrm{j}$ shares common border with Kenya and zero otherwise;

$W T O_{j}$ is a dummy variable if a trading partner is WTO member is coded one and zero otherwise.

$U_{i j t}$ is the error term;

$\beta_{0}$ is the constant;

$\beta_{1} \ldots \ldots \beta_{11}$ estimated parameters.

According to the literature, the theory states that the coefficients of domestic and foreign GDP are supposed to be positive as both exporters and importers' income increases export outflows. Martínez-Galán, Fontoura, and 
Proença (2005) argued that GDP should be an appropriate measure of the potential trade of the country. Real GDP per capita of the importer is used to assess the type of the product. Its coefficient is expected to have a positive sign for the case of a luxury good and a negative sign in the case of necessity(Bergstrand, 1985). Kenya's per capita income is used as a proxy for resource use in the production of tea and trade theory explaining the exports. A negative (positive) sign of the coefficient entails that commodity is labor- (capital-) intensive and resource endowments in the country describe the reason for exports.

As suggested by most previous empirical studies, the impact of population size (POP) is mixed. The population variable can affect exports in two ways and therefore, the population coefficients in both I and $\mathrm{j}$ are uncertain (Joel Hinaunye Eita \& Jordaan, 2007). Markheim (1994) contends that a country with a large population size involves a large domestic market, a high degree of self-sufficiency and a decreased need for trade (absorption effect). Other argument shows that a large population means more development in the specialization and division of labor and production increase, which is generally associated with a greater need for trade (scale effect). (Joel Hinaunye Eita \& Jordaan, 2007; Oguledo \& MacPhee, 1994) in their studies, it was specified that the population effects could not be assigned a priori to both exporting and importing countries, meaning that the population sign may be negative or positive.

The distance coefficient is assumed to be negative because of the greater distance between the two countries ' economic centers increases the cost of goods transportation between them. The high such cost, the lower trade should be (Kristjánsdóttir, 2005; Longo \& Sekkat, 2004).

The impact of the real exchange rate variable on bilateral trade between Kenya and other countries is expected to be negative. A relative change in the exchange rate is expected to affect a country's import and export volumes as it can increase or decrease commodity prices in both domestic and foreign currencies. Depreciation of currency allows a country to export more and import less, while appreciation can enable a country to export less and import more. (Bergstrand, 1985).

The common colony coefficient is expected to be positive. On the other hand, neighboring countries are associated with lower transportation and transaction costs. We, therefore, expect a positive coefficient to describe exports to countries that share a common border with Kenya.

The coefficient of COMESA would be positive as Kenya is a member of such integration; hence it faces preferential tariffs on its exports to COMESA nations. On the other hand, the coefficients of the other region of the EU and Asia expected to be mixed depending on the relationship between Kenya and the region.

WTO refers to the GATT/WTO membership of Kenya's trade partners. According to conventional wisdom, WTO members exchange more, so a positive coefficient is most predicted for this parameter.

\subsection{Data sources}

The present study uses panel data for the analysis of gravity model and panel data is more appropriate than timeseries data and cross-section data (Egger, 2000) because of the model misspecification that can emerge from timeseries and cross-section data. Panel data controls heterogeneity, it also offers more variability and more degree of freedom and it reduces collinearity. More importantly, panel data can monitor the individual effects of the observed trading partner - pairs that are not detectable in cross-sections and time-series data (Baltagi \& Li, 2004). (Egger, 2002; Joel H Eita, 2008; Filippini \& Molini, 2003; Martínez-Zarzoso \& Nowak-Lehmann, 2003; Mátyás, 1997)used panel data to approximate gravity equations, among others, and argued that panel data specifications are more suitable and useful in describing bilateral trade flows and evaluating factors that contribute to these trade flows compared to cross-sectional and time-series data.

In sum, the annual data covers 15 countries for the years 1990 to 2017 with one dependent variable and 11 explanatory variables $(\mathrm{n}=15, \mathrm{~T}=27, \mathrm{~N}=420)$, and all variables are expressed in natural logarithm. These countries were chosen based on their importance as trading partners for Kenya and the availability of data for different variables. The data on Real GDP, GDP per capita and the population were obtained from The World Bank' Development Indicators (WBDI). The data on the values of Kenya's tea exports to specific countries were obtained from the UN COMTRADE database under classification SITC REV2. Data on dummy variables (COMESA, Eu, Common Border, Common colonial links, Island and WTO) and data on distance in kilometers between Nairobi (capital of Kenya) and capital of country $j$ was obtained from the following website:http://www.cepii.fr/CEPII/en/bdd_modele/presentation.asp?id=6

The bilateral real exchange rate between Kenya and trading partner was calculated using the real exchange rate definition of the IMF: real exchange rate as domestic currency price against foreign currency as in the following formula:

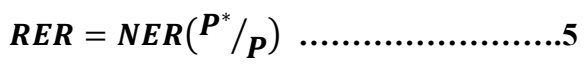

Where RER is the real exchange rate, NER is the bilateral nominal exchange rate, $\mathrm{P} *$ is the consumer price index 
of the foreign country and $\mathrm{P}$ is the domestic consumer price index (Kenya in this case). Nominal exchange rates and consumer price index were collected from the UNCTAD database. The information on common language and regional trade agreements were obtained from world trade statistics. Data processing and empirical estimations were conducted on $\mathrm{R}$.

\subsection{Estimation methods}

There are three distinct techniques available to estimate linear panel models. These are pooled ordinary least square (POLS), secondly, fixed effect method (FE) and thirdly, random effect method (RE) (Gujarati \& Porter, 2003). The most straightforward approach is pool estimation; its function is as follow,

$Y_{i t}=\alpha+\beta X_{i t}+\varepsilon_{i t}$ . .6

Where $\mathrm{i}$ stands for the cross-sectional unit, $\mathrm{t}$ stands for the time and the error term is normally distributed with mean zero and constant variance. The main problem with the pooled model is that it does not permit heterogeneity in countries. It fails to predict country impacts in all nations and assumes homogeneity; it is a restricted model. (Egger, 2000)

The fixed effect takes the individual and time effects into account by allowing the intercept to vary for each individual and time period, but the slope coefficients are constant, the model is:

$Y_{i t}=\alpha_{i}+\beta X_{i t}+\varepsilon_{i t}$ .7

If the flow of trade is estimated between the predefined set of countries, then the fixed effects model is considered to produce better results. (Egger, 2000) The fixed effect model is estimated by least squares dummy variable (LSDV) regression (OLS with a set of dummies) and within the effect estimation methods.

To choose between a pooled regression model and a fixed-effect model, a $\mathrm{f}$ test is performed. If the null hypothesis is rejected you may conclude that there is a significant fixed effect or increase in goodness-of-fit in the fixed effect model; the fixed effect is, therefore, better than POLS (Dascal et al., 2002)

The following formula is used to measure the F-statistic:

$$
F=\frac{\left(R_{F E}^{2}-R_{C C}^{2}\right) /(N-1)}{\left(1-R_{F E}^{2}\right) /(N T-N-K)} \approx F(N-1, N T-N-K) \ldots \ldots .8
$$

Where $R_{F E}^{2}$ and $R_{C C}^{2}$ are the coefficient of determination of fixed effect model and common constant model, respectively.

The third model; the random effect model, assumes that each group differs in its error term so random effect model can be modeled as:

$Y_{i t}=\alpha_{i}+\beta X_{i t}+\left(V_{i}+\varepsilon_{i t}\right)$ . .9

The random effect model is useful if we want to estimate a country's trade flow with its trading partners and those trading partners have been chosen from many other countries (from quite a large population)

The principal distinction between the random and the fixed effect model is that the random effect models assume that there is no correlation between the individual effects and the regressors, while a fixed effect model allows for this correlation. To differentiate between fixed effect and random effect Hausman specification test will be applied(Egger, 2000).

$H=\left(\beta^{\wedge F E}-\beta^{\wedge R E}\right)^{\prime}\left[\operatorname{Var}\left(\beta^{\wedge F E}\right)-\operatorname{Var}\left(\beta^{\wedge R E}\right)\right]^{-1}\left(\beta^{\wedge F E}-\beta^{\wedge R E}\right) \approx x^{2}(K)$

If the null hypothesis of no correlation is rejected, you may conclude that individual effects are significantly correlated with a least one regressor in the model; thus random effect model is problematic. Therefore, the fixed effect model is appropriate.

The fixed effects model has a problem in the way that variables that do not change over time cannot be directly estimated because such variables are wiped out by inherent transformation. In a second stage regression, to solve this problem, these variables can be estimated by estimating another regression with individual effects as the dependent variable and as independent distance and dummy variables. This is specified as follows: 
$E_{i j}=\beta_{0}+\beta_{1}\left(\operatorname{gdp}_{i t}\right)+\beta_{2}\left(D_{i j}\right)+\beta_{3}\left(\right.$ island $\left._{j}\right)+\beta_{4}\left(\operatorname{ComCol}_{i j}\right)+\beta_{5}\left(e u_{j}\right)+\beta_{6}\left(\right.$ Asia $\left._{j}\right)+$ $\beta_{7}\left(\operatorname{Comesa}_{j}\right)+\beta_{8}\left(\operatorname{commonB}_{i J}\right)+\left(U_{i j t}\right) \ldots . .11$

$E_{i j}$ are individual effects and other variables, as previously defined.

To test the significance of random effects, Lagrange Multiplier (LM) tests developed by Breusch and Pagan (1980)could be utilized based on the residuals from POLS estimation. If LM test rejects the null hypothesis that the variance of the residuals equals zero, the RE estimator is preferred to the POLS estimates and vice versa.

Empirical work on applying the gravity model does not give a clear answer on which estimation method pooled estimation, random or fixed effect does give more efficient results. Therefore, first, the trade equation will be estimated by all three methods, then F statistic test and Hausman test and Breusch and Pagan Lagrangian multiplier (lm) test (Verbeek, 2008) will be run to select the most efficient method for interpreting the estimate results.

\section{Empirical results.}

The estimated results of bilateral trade between Kenya and trading partners using the gravity equation are presented in table 1. The first column displays the results of pooled estimation while the fixed effect and random effect method are reported in columns two and three, respectively as suggested by Cheng and Wall (2005). The issue with POLS is that it does not take into account countries' heterogeneity and no country-specific impacts are estimated, hence assuming that all countries are homogeneous in terms of cross-section and time. By estimating country-specific effects, the fixed-effect model presents heterogeneity. It is in an unrestricted model because it enables intercept and other parameters to vary across trading partners. A formal test for a fixed-effect model and a Pooled OLS model is used as the basis for our comparison to verify which model is better. The highly significant value of the F-test $(\mathrm{F}=28.03)$ counted against the null hypothesis that the Pooled OLS model was adequate in favor of the fixed effects alternative. This implies that the fixed effects model is better than the pooled model.

The random effect model recognizes heterogeneity as fixed effect model in the cross-section. It differs from the fixed effects model, however, in that a particular distribution generates the effects. Although it assumes that the cross-section is heterogeneous, it does not explicitly model each effect. The Breusch-Pagan LM test for random effect Again rejects the cross-section homogeneity null hypothesis in favor of the random effect specification again rejects the null hypothesis of cross-section homogeneity in support of the random effect specification.

Hausman statistics are often used to differentiate between the random effect model and the fixed effect model. These statistics test whether the individual effects and regressor correlation exists. Table 1 results show that the Hausman test rejects the null hypothesis, which indicates that country-specific effects are correlated with regressors. This calls for the implementation of the fixed effect model. Because the fixed-effect model has been discovered to be suitable compared to other models, we will interpret our results based on the fixed effect model.

The results of the fixed-effect model, as shown in the table, indicate the positive sign coefficient in Kenya's GDP, but it is not a significant value. This means that it cannot be considered as an explanatory variable for the demand for Kenyan tea.

An increase in the importer country's GDP causes an increase in Kenyan tea exports. The highly significant value of the importer country's GDP is positive. This means that holding constant other variables, an increase of one percent of the importer country's GDP will result in roughly a $2.00 \%$ increase in Kenya's exports. This result is in line with the fundamental assumption of the gravity model that the volumes of trade will increase with an increase in economic size.

Our gravity model results indicate a positive coefficient for Kenya's population. It means that an increase in the population of Kenya causes an increase in tea exports, but the coefficient is not statistically significant. This suggests that Kenya's population has no significant impact on exports. 
Table 1: Gravity model estimation results

\begin{tabular}{|c|c|c|c|}
\hline & POL & FE & $\mathbf{R E}$ \\
\hline \multirow[t]{2}{*}{ (Intercept) } & -22.94 & & -6.84 \\
\hline & $(22.52)$ & & (21.23) \\
\hline \multirow[t]{2}{*}{ Lngdpi } & $1.79^{* *}$ & 0.67 & $1.34^{*}$ \\
\hline & $(0.57)$ & $(0.46)$ & $(0.53)$ \\
\hline \multirow[t]{2}{*}{ Lngdpj } & $-2.16^{* * *}$ & $2.00^{* * *}$ & -0.58 \\
\hline & $(0.24)$ & $(0.37)$ & $(0.32)$ \\
\hline \multirow[t]{2}{*}{ Lnpopi } & $-3.18^{*}$ & 0.45 & -2.42 \\
\hline & $(1.61)$ & $(1.31)$ & $(1.49)$ \\
\hline \multirow[t]{2}{*}{ Lnpopj } & $4.14^{* * *}$ & $-3.63^{* * *}$ & $2.22^{* * *}$ \\
\hline & $(0.27)$ & $(0.66)$ & $(0.39)$ \\
\hline \multirow[t]{2}{*}{ Lndistance } & -0.08 & & -0.88 \\
\hline & $(0.43)$ & & $(0.69)$ \\
\hline \multirow[t]{2}{*}{ Lnrer } & $0.34^{* *}$ & $0.33^{* *}$ & $0.35^{* *}$ \\
\hline & $(0.12)$ & $(0.11)$ & $(0.12)$ \\
\hline \multirow[t]{2}{*}{ lngdppercapitai } & -1.25 & -0.59 & -0.98 \\
\hline & $(1.57)$ & $(1.23)$ & $(1.44)$ \\
\hline \multirow[t]{2}{*}{ lngdppercapitaj } & $3.96^{* * *}$ & $-3.11^{* * *}$ & $1.37^{* *}$ \\
\hline & $(0.37)$ & $(0.62)$ & $(0.50)$ \\
\hline \multirow[t]{2}{*}{ Island } & 0.44 & & $5.26^{* * *}$ \\
\hline & $(0.90)$ & & $(1.41)$ \\
\hline \multirow[t]{2}{*}{ ComCol } & $3.36^{* * *}$ & & $2.69^{* * *}$ \\
\hline & $(0.33)$ & & $(0.55)$ \\
\hline \multirow[t]{2}{*}{$\mathrm{Eu}$} & $1.76^{* * *}$ & & 0.24 \\
\hline & $(0.48)$ & & $(0.83)$ \\
\hline \multirow[t]{2}{*}{ Asia } & $1.40^{* *}$ & & 0.52 \\
\hline & $(0.44)$ & & $(0.78)$ \\
\hline \multirow[t]{2}{*}{ Comesa } & $4.65^{* * *}$ & & $3.76^{* * *}$ \\
\hline & $(0.64)$ & & $(1.11)$ \\
\hline \multirow[t]{2}{*}{ CommonB } & $-4.02^{* * *}$ & & $-2.84^{*}$ \\
\hline & $(0.65)$ & & $(1.12)$ \\
\hline \multirow[t]{2}{*}{ WTO } & $2.17^{* * *}$ & $1.53^{* * *}$ & $1.64^{* * *}$ \\
\hline & $(0.50)$ & $(0.43)$ & $(0.48)$ \\
\hline$\overline{\mathrm{R}^{2}}$ & 0.78 & 0.38 & 0.55 \\
\hline Adj. $R^{2}$ & 0.77 & 0.34 & 0.53 \\
\hline F-test & & $28.03 * * *$ & \\
\hline LM & & & $46.3 * * *$ \\
\hline Hausman test & & $* * *$ & \\
\hline
\end{tabular}

RMSE 1.48

${ }^{* * *} \mathrm{p}<0.001,{ }^{* *} \mathrm{p}<0.01,{ }^{*} \mathrm{p}<0.05$ All other variables are statistically insignificant. Standard error are in parenthesis.

Results on the influence of the population of Kenya's trade partners reveal that an increase in the partners' population by one unit leads to a decline in the trend of the flow of tea exports. The negative relationship between trade flow and trade partner's population can be attributed to a condition referred to as an exporter substitution effect. That is, as the trade partner countries ' population is growing larger, people are working harder and production increases to meet their domestic market demands. Studies by (Aitken, 1973; Bikker, 1987) found a negative and significant coefficient for the population of the importing country.

As hypothesized, the exchange rate coefficient shows a significant positive value of 0.33 , which means that the depreciation in Kenya's shilling by one percent against the currency of the trading partner countries would stimulate Kenya's tea exports by $0.33 \%$.

The coefficient of importer's GDP per capita is negative and significant. This result suggests that an increase in GDP per capita of the importing country causes a decrease in demand for Kenyan tea export.

WTO variable has a positive coefficient and it is statistically significant. The more Kenya trades with WTO members, its tea exports are expected to increase by $1.53 \%$. 
Table 2: Second stage regression fixed effects regressed on dummies.

\begin{tabular}{ll}
\hline & Model 1 \\
\hline (Intercept) & $-16.06^{* * *}$ \\
& $(3.45)$ \\
Lndistance & $-2.82^{* * *}$ \\
& $(0.42)$ \\
Island & $5.29^{* * *}$ \\
& $(0.88)$ \\
ComCol & $1.52^{* * *}$ \\
& $(0.35)$ \\
Eu & 0.75 \\
& $(0.60)$ \\
Asia & 0.94 \\
& $(0.64)$ \\
Comesa & $6.04^{* * *}$ \\
CommonB & $(0.84)$ \\
& $1.69^{*}$ \\
$\mathrm{R}^{2}$ & $(0.71)$ \\
Adj. $\mathrm{R}^{2}$ & 0.47 \\
$\mathrm{RMSE}^{* * *} \mathrm{p}<0.001,{ }^{* *} \mathrm{p}<0.01,{ }^{*} \mathrm{p}<0.05$ & 0.46 \\
& \\
\end{tabular}

The distance variable is significant and bears the anticipated negative sign, as shown in Table 4. Distance, therefore, has an inverse relationship with exports. The distance was factored in as a proxy for transportation costs. The negative coefficient value indicates that when the distance between Kenya and its trading partner increases by $1 \%$, the value of exports to this destination decreases by approximately $2.82 \%$. The relationship implies that the further the importer is from Kenya, the higher the transport costs and therefore the lower the exports to that particular country.

The sharing of common border and island countries has a positive coefficient and they are statistically significant. Theory suggests that the cost of trade is low when there is trade between non-landlocked countries and lower costs are linked to countries sharing a common border. (see Anderson and Van Wincoop, 2001; Jansen and Piermartini, 2009). Our study results confirm that Kenyan tea export acceleration is positively linked to countries sharing a common border with Kenya and non-landlocked (island) countries.

Results indicate significant and robust positive explanatory power between Kenyan tea export flows and colonial linkage, which is reasonable to expect because marketing/trade linkages in regions that were once formed part of the British Empire would support existing trade relations and promote tea exports to those markets.

The coefficient of EU and Asia is positive as expected, but it is not significant. Moreover, being a member of COMESA (Common Market for Eastern and Southern Africa) integration has a positive and significant impact on Kenya's tea exports. This is to be anticipated because Kenya is a member of COMESA, which means that her tea exports encounter little barriers to trade and receive preferential treatment in the Member States.

\section{Conclusion}

Tea exports play a crucial role in the Kenyan economy because they are one of the leading exports, our analysis, therefore, seeks to identify the factors influencing Kenya's exports of tea to its primary import market. The gravity model was applied using the 1990-2018 panel data to identify these factors influencing Kenyan tea exports to its 15 major importers.

The pooled ordinary least square, random effect and fixed effect estimations were made based upon the panel data. Since the null hypothesis was rejected (random effects were efficient) by the Hausman test, so the fixed effect model result was considered reliable and based upon the fixed model results. The findings revealed that the tea export flows from Kenya to majors 15 countries of the world are driven by GDP of trading partner, the population 
of the importing partner, Importing partner's Per capita GDP, exchange rates, membership of trading partner in WTO and COMESA, distance from Kenya to the importing country if the importing country shares the common colony with Kenya and lastly if the importing partner is not a landlocked country.

The findings from our analysis show that 15-tea importer's economic growth would have a substantial impact on Kenya's tea exports. Therefore, it appears more desirable for Kenya to promote tea to countries with large economies to expand bilateral trade flows. Importer's population and GDP per capita turned out to influence Kenyan exports negatively.

Exchange rates have been found an impacting factor on the tea exports from Kenya to its major 15 trading partners. Depreciation in Kenyan shilling would stimulate the tea exports from Kenya. But Kenya's Central Bank should manage the exchange rates effectively because depreciation would also have a negative impact on the economy i.e., it will result into inflation.

The distance between Kenya and importing countries was used as a proxy of transportation costs, it was found that an increase in the distance reduces the tea exports, while it was found that if Kenya trades with countries that they share common border, there are more tea exports. Kenya should trade more with countries with closer proximity. Also, countries which are not landlocked have more demand for tea exports since they have a seaport, which reduced the cost of transportation compared to landlocked countries where they have to use other means of transport.

Following the positive influence of the common colony on the exports of Kenyan tea. It is proposed that Kenya try to focus on the countries colonized by Britain. The impact of importing country being a member of COMESA is positive. To benefit from existing preferential arrangements, Kenya could extend its exports to the COMESA region.

\section{References}

Ahmad, B., \& Garcia, R. J. (2012). Measuring Commodity-Specific Trade Determinants and Export Potential: A Gravity Model of Pakistan's Rice Exports. Journal of International Agricultural Trade and Development, $8(2), 125$.

Aitken, N. D. (1973). The effect of the EEC and EFTA on European trade: A temporal cross-section analysis. The American Economic Review, 63(5), 881-892.

Anderson, J. E. (1979). A theoretical foundation for the gravity equation. The American Economic Review, 69(1), $106-116$

Awokuse, T. O., \& Xie, R. (2015). Does agriculture really matter for economic growth in developing countries? Canadian Journal of Agricultural Economics/Revue canadienne d'agroeconomie, 63(1), 77-99.

Baltagi, B. H., \& Li, D. (2004). Prediction in the panel data model with spatial correlation. In Advances in spatial econometrics (pp. 283-295): Springer.

Bergstrand, J. H. (1985). The gravity equation in international trade: some microeconomic foundations and empirical evidence. The Review of Economics and Statistics, 474-481.

Bikker, J. A. (1987). An international trade flow model with substitution: an extension of the gravity model. Kyklos, 40(3), 315-337.

Breusch, T. S., \& Pagan, A. R. (1980). The Lagrange multiplier test and its applications to model specification in econometrics. The review of economic studies, 47(1), 239-253.

Brülhart, M., \& Kelly, M. J. (1999). Ireland's trading potential with central and eastern European countries: A gravity study. Economic and Social Review, 30, 159-174.

Cheruiyot, K. (2013). Impact of integrated supply chain on performance at Kenya Tea Development Agency. International Journal of Social Sciences and Entrepreneurship, 1(5), 194-203.

Christiaensen, L., Demery, L., \& Kuhl, J. (2011). The (evolving) role of agriculture in poverty reduction-An empirical perspective. Journal of development economics, 96(2), 239-254.

Commission, K. H. R. (2008). A Comparative Study of the Tea Sector in Kenya; A Case Study of Large Scale Tea Estates.

Cortes, M. (2007). Composition of Trade between Australia and Latin America: Gravity Model.

Dascal, D., Mattas, K., \& Tzouvelekas, V. (2002). An analysis of EU wine trade: a gravity model approach. International Advances in Economic Research, 8(2), 135-147.

Egger, P. (2000). A note on the proper econometric specification of the gravity equation. Economics letters, 66(1), 25-31.

Egger, P. (2002). An econometric view on the estimation of gravity models and the calculation of trade potentials. World Economy, 25(2), 297-312.

Eita, J. H. (2008). Determinants of Namibian Exports: A gravity model approach. Paper presented at the 13th African Econometric Conference, University of Pretoria, South Africa.

Eita, J. H., \& Jordaan, A. C. (2007). South Africa's Wood Export Potential Using a Gravity Model Approach. Department of Economics: University of Pretoria. 
Faostat, F. (2018). Agriculture organization corporate statistical database. In.

FAOSTAT, F. (2018). FAOSTAT statistical database. In.

Filippini, C., \& Molini, V. (2003). The determinants of East Asian trade flows: a gravity equation approach. Journal of asian Economics, 14(5), 695-711.

Gujarati, D. N., \& Porter, D. C. (2003). Basic econometrics (ed.). New York: McGraw-HiII.

Hatab, A. A., Romstad, E., \& Huo, X. (2010). Determinants of Egyptian agricultural exports: A gravity model approach. Modern Economy, 1(03), 134.

Houghton, J., \& Sheehan, P. (2000). A primer on the knowledge economy.

Jensen, H. G., \& Sandrey, R. (2015). African agricultural trade: Recent and the future. African Journal of Agricultural and Resource Economics, 10(311-2016-5627), 146.

Kristjánsdóttir, H. (2005). A gravity model for exports from Iceland. Centre for Applied Microeconometrics, Department of Economics, University of Copenhagen.

Linnemann, H. (1966). An econometric study of international trade flows: North-Holland Pub. Co.

Lof, M., Mekasha, T. J., \& Tarp, F. (2015). Rejoinder to Herzer, Nowak-Lehmann, Dreher, Klasen, and MartinezZarzoso (2014). World Development, 70, 397-399.

Longo, R., \& Sekkat, K. (2004). Economic obstacles to expanding intra-African trade. World Development, 32(8), 1309-1321.

Markheim, D. (1994). A note on predicting the trade effects of economic integration and other preferential trade agreements: An assessment. J. Common Mkt. Stud., 32, 103.

Martínez-Galán, E., Fontoura, M. P., \& Proença, I. (2005). Trade Potential in an Enlarged European Union: a recent approach. Retrieved from

Martínez-Zarzoso, I., \& Nowak-Lehmann, F. (2003). Augmented gravity model: An empirical application to Mercosur-European Union trade flows. Journal of applied economics, 6(2), 291-316.

Mátyás, L. (1997). Proper econometric specification of the gravity model. World Economy, 20(3), 363-368.

Mulinge, W., Witwer, M., \& Monroy, L. (2013). Analysis of incentives and disincentives for tea in Kenya.

Oguledo, V., \& MacPhee, C. R. (1994). Gravity models: a reformulation and an application to discriminatory trade arrangements. Applied Economics, 26(2), 107-120.

Orindi, M. N. (2010). Determinants of Kenyan exports: A gravity model approach. University of Nairobi, Kenya,

Ricchiuti, G. (2004). Empirical Evidence on the North-South Trade Flows: an Augmented Gravity Model. Retrieved from

Tinbergen, J. (1962). An analysis of world trade flows. Shaping the world economy, 3, 1-117.

Verbeek, M. (2008). A guide to modern econometrics: John Wiley \& Sons. 